\title{
Select document: the Prescott-Decie letter
}

$\mathrm{W}$ hat was the nature and extent of the British government's responsibility for reprisals in the summer and autumn of 1920, during the Irish War of Independence? The government's public position at the time - that they were doing everything possible to prevent reprisals, which were infrequent and exaggerated - is widely discounted. The question is rather: did the government initiate reprisals, or merely tolerate them? Did they make reprisals happen, or only let them happen? At the time, Irish revolutionaries were convinced that reprisals were official policy: the Irish Bulletin said 'there is a definite Governmental policy of settling England's difficulties by a campaign of terrorism directed indiscriminately against the Irish people as a whole. ${ }^{1}$ Since the 1970s, by contrast, most historians have accepted that the initiative for reprisals came from below. 'Reprisals were not, in the first instance, a "deliberate act of government policy",' says D. G. Boyce. 'They were to the Irish police a means of retaliation against a ruthless and elusive enemy who, they alleged, was enjoying "the usual advantages of guerrilla warfare without suffering any of the penalties attached to it".'2 And aside from occasional suggestions that the government may have done more than just condone reprisals, ${ }^{3}$ historians have generally agreed that the British government sinned more by omission than by commission.

But in their recent article 'Smoking gun? RIC reprisals, summer 1920', John Borgonovo and Gabriel Doherty have challenged this consensus, by providing 'indisputable evidence' that 'Dublin Castle had authorised an assassination campaign against its republican opponents' ${ }^{4}$ This indisputable evidence consists of passages from a 'newly discovered' document ${ }^{5}-$ a secret letter from a senior

\footnotetext{
1 'From martial law to martial lawlessness' in Irish Bulletin, 5 Oct. 1920, p. 1.

${ }^{2}$ D. G. Boyce, Englishmen and Irish troubles: British public opinion and the making of Irish Policy, 1918-1922 (Cambridge, MA, 1972), p. 54. See also Charles Townshend, The British campaign in Ireland 1919-1921: the development of political and military policies (Oxford, 1975); Joost Augusteijn, From public defiance to guerrilla warfare: the experience of ordinary volunteers in the Irish War of Independence 1916-1921 (Dublin, 1996); D. M. Leeson, The Black and Tans: British police and Auxiliaries in the Irish War of Independence (Oxford, 2011).

${ }^{3}$ See, for example: David Fitzpatrick, Politics and Irish life 1913-1921: provincial experience of war and revolution (Dublin, 1977); Tom Bowden, The breakdown of public security: the case of Ireland 1916-1921 and Palestine 1936-1939 (London and Beverly Hills, 1977); Michael Hopkinson, The Irish War of Independence (Montreal, Kingston, and Ithaca, 2002).

${ }^{4}$ John Borgonovo and Gabriel Doherty, 'Smoking gun? RIC reprisals, summer 1920' in History Ireland, xvii, no. 2 (Mar./Apr. 2009), pp 36-9, at p. 39.

${ }^{5}$ Borgonovo and Doherty, 'Smoking gun,' p. 38.
} 
police officer to a senior civil servant. Brigadier-General Cyril Prescott-Decie was the Royal Irish Constabulary's divisional commissioner for Clare, Limerick, and northern Tipperary. In his letter, dated 1 June 1920, the brigadier-general was reporting to Dublin Castle about conditions within his division. Towards the end of the letter, Prescott-Decie says the following:

I have been told the new policy and plan and I am satisfied, though I doubt its ultimate success in the main particular - the stamping out of terrorism by secret murder. I am still of opinion that instant retaliation is the only course for this, and until it is stamped for good and all, the same situation is likely to recur. ${ }^{6}$

According to Borgonovo and Doherty, there is only one way to interpret this passage: 'the stamping out of terrorism by secret murder' must refer to a 'new policy and plan' of extrajudicial killings. 'The letter', they say, 'reveals a disturbing policy of assassination sanctioned by the highest level of the British government in Ireland. ${ }^{7}$ What is more, this policy was in place by the spring of 1920 - 'months earlier than commonly believed' - and its implements were not just the Black and Tans, but also 'regular, Irish-born members of the RIC'. 'Indeed', they conclude, 'the proactive rather than reactive nature of the policy and its explicit "top-down" sanction by top officials in the "Irish Government" bring into question whether the word - nay, the very concept of - "reprisal" needs to be fundamentally revised.' 8

Not all historians have agreed with this conclusion. In a letter to History Ireland, David Fitzpatrick has pointed out that this document was not a new discovery: indeed, Fitzpatrick himself had discussed Prescott-Decie's letter in his book Politics and Irish life 1913-1921, published in 1977. .' Fitzpatrick argued that Borgonovo and Doherty were misreading the letter's crucial passage: the 'secret murder' in question was being committed by the 'terrorists' of the I.R.A.; and it was this 'terrorism by secret murder' that the 'new policy and plan' was intended to stamp out. ${ }^{10}$ But Borgonovo and Doherty have defended their own interpretation, 'which is based on the plain meaning of the crucial sentences'. ${ }^{11}$

There are, however, problems with Borgonovo and Doherty's theory. They argue that 'Dublin Castle authorized an assassination campaign against its

${ }^{6}$ C. Prescott-Decie to assistant under-secretary, 1 June 1920 (N.A.I., Crime Special Branch other papers, Box 24), reproduced in Borgonovo and Doherty, 'Smoking gun,' p. 37 , and below.

${ }^{7}$ Borgonovo and Doherty, 'Smoking gun,' p. 37.

${ }^{8}$ Ibid., p. 38.

9 Fitzpatrick, Politics and Irish life, pp 29-30. The Prescott-Decie letter was also discussed in the 1970s by Tom Bowden, in his article 'Bloody Sunday - a reappraisal' in European Studies Review, ii, no. 1 (1972), pp 25-42, at p. 34 and his book The breakdown of public security, p. 119. It was also mentioned briefly by Charles Townshend in his reply to Bowden, 'Bloody Sunday - Michael Collins speaks' in European Studies Review, ix, no. 3 (1979), pp 377-85, at p. 383, n. 6. Twenty years later, Fitzpatrick mentioned the Prescott-Decie letter in The two Irelands 1912-1939 (Oxford and New York, 1998), p. 91. The passage in question was even quoted in Piaras Béaslaí, Michael Collins: soldier and statesman (Dublin, 1937), p. 182.

${ }^{10}$ David Fitzpatrick, 'RIC reprisals, summer 1920' [letter to the editor], in History Ireland, xvii, no. 3 (May/June 2009), pp 12-13.

${ }^{11}$ John Borgonovo and Gabriel Doherty, 'Prescott-Decie letter' [letter to the editor], in History Ireland, xvii, no. 4 (July/Aug. 2009), p. 12. 
republican opponents' in the spring of 1920. If that is true, then - where are the bodies? Extrajudicial killings by the police did not become a prominent feature of the War of Independence until the autumn. Take, for example, west Galway. Recall that Prescott-Decie's letter is dated 1 June 1920. There were no extrajudicial killings in west Galway in June 1920. There were also no extrajudicial killings in July, though police did riot in Tuam, after two constables were killed in an ambush. There were still no extrajudicial killings in August, even after an ambush claimed the life of a third constable, and police took reprisals in Oranmore. ${ }^{12}$ In fact, no republican activists were killed in west Galway until September. On the night of 8 September 1920, Sean Mulvoy was killed in a fight with a Black and Tan at Galway railway station: and in the reprisals that followed, Seamus Quirke was summarily executed by a police firing squad. ${ }^{13}$ But no republicans were actually assassinated in west Galway until October 1920, when city councillor Michael Walsh was abducted and murdered on the night of 19 October. ${ }^{14}$ More than a month passed before the security forces claimed their next victim, Fr Michael Griffin, who was abducted and murdered on the night of 14 November. ${ }^{15}$ If Dublin Castle did authorise a programme of assassination in the spring, it seems odd that more than five months would elapse before the first of these assassinations was carried out in Galway.

Furthermore: Borgonovo and Doherty claim that this policy of extrajudicial killings must have been sanctioned from the top down - by 'top officials in the Irish government'. If that is true, then: who were these top officials? Whose hidden hand was at work? Prescott-Decie's letter is addressed simply to the assistant under-secretary for Ireland. According to Borgonovo and Doherty, this was Sir John Taylor, who they describe as 'one of the most influential civil servants in Dublin Castle' and 'a noted hawk on security matters who had consistently opposed concessions to nationalist opinion'. ${ }^{16}$ But Sir John Taylor was no longer in office by 1 June 1920, when Prescott-Decie wrote his letter. The assistant under-secretary had been granted a month's leave, at his own request, in mid-April 1920, and had retired in mid-May. ${ }^{17}$ Indeed, Sir John Taylor's retirement was reported in the British press, on 24 May 1920. The report in the Times even suggests that Taylor's retirement 'will be regarded in Ireland as evidence that more moderate counsels are likely to prevail in the future'. ${ }^{18}$

By the time Prescott-Decie wrote his letter, there was a new assistant undersecretary: Alfred 'Andy' Cope - a man whom Charles Townshend has described as the moving spirit of the 'peace party' in Dublin Castle. ${ }^{19}$ According to Keith

\footnotetext{
${ }^{12}$ Leeson, The Black and Tans, pp 42-5.

${ }^{13}$ Ibid., p. 45.

${ }^{14}$ Ibid., p. 49.

${ }^{15}$ Ibid., p. 52.

16 Borgonovo and Doherty, 'Smoking gun,' pp 36, 38.

17 Townshend, British campaign in Ireland, pp 76-81; Hopkinson, Irish War of Independence, pp 36, 59-63. Both of these works are included in the suggestions for further reading at the conclusion of Borgonovo and Doherty's article.

18 'Changes at Dublin Castle,' The Times, 24 May 1920, p. 8; 'Sir J. Taylor Retires,' Manchester Guardian, 24 May 1920, p. 5.

${ }_{19}$ Townshend, British campaign in Ireland, p. 99. Cope's appointment as Taylor's replacement is reported in both of the news articles mentioned above.
} 
Middlemas, 'Cope dismissed a number of civil servants known to be prejudiced against Sinn Féin and he himself conducted most of the secret negotiations with Irish leaders. ${ }^{20}$ In fact, it seems that hard-liners in Dublin Castle thought Cope was almost a republican himself. ${ }^{21}$ By the summer of 1920, the Royal Irish Constabulary's deputy inspector-general was an officer named Charles Walsh. Fifty years later, Walsh's daughter recalled that,

The British Govt. with Lloyd George as P.M. sent over to Ireland the most thick-headed and pro I.R.A. like Birrell and Cope. My father always used to remark how strange it was that Cope could walk all over the streets \& alleyways in Dublin without ever being challenged by the I.R.A. ${ }^{22}$

It seems unlikely that Cope would (or even could) have masterminded a secret campaign of extrajudicial killings within a week of his appointment. ${ }^{23}$

This raises another problem with Borgonovo and Doherty's theory: the lack of corroborating evidence. As the authors themselves admit, 'no evidence has been found that links assassination reprisals directly to Dublin Castle' ${ }^{24}$ There is, moreover, evidence that at least one senior Castle official was opposed to reprisals, which he blamed on police frustration and loss of self-control. On 23 July 1920 the top civil servants in the Irish government attended a cabinet conference in London, where all but one of them argued in favour of a negotiated settlement: only the Police Adviser, Major-General Henry Hugh Tudor, disagreed ${ }^{25}$ The first official to make the case for negotiation was the Law Adviser, William Evelyn Wylie, who said that 'he had during the last three weeks seen a large number of police officers, and had formed the strong opinion that within two months the Irish Police Force as a Police Force would cease to exist'. The conditions under which the men of the Royal Irish Constabulary were serving would reduce them to little more than armed bands. Those who had not resigned from fear of being murdered would be committing murder themselves.

In two months' time, fifty per cent. of the Police Force would have resigned through terrorism, and the remainder would have to go about in considerable force committing counter outrages. Am [sic] Irish policeman either saw white or he saw red; if he saw white, he resigned from the Force through terrorism, and if he saw red he committed a counter outrage.

${ }^{20}$ Thomas Jones, Whitehall Diary, ed. Keith Middlemas (3 vols., London, 1975), iii, 25 note.

21 Townshend, British campaign in Ireland, p. 80; Hopkinson, Irish War of Independence, p. 62.

${ }^{22}$ Finola Morrison to J. R. W. Goulden, 7 December 1971, (T.C.D., Goulden Papers, no. 175). Morrison even accuses Cope (on her father's authority) of warning Michael Collins about an impending police raid, and allowing the I.R.A. leader to escape.

${ }^{23}$ To make matters worse, the authors also refer to 'Dublin Castle senior civil servant Mark Sturgis' and 'his superior, under-secretary Andy Cope.' In fact, both Alfred Cope and Mark Sturgis were assistant under-secretaries: the joint under-secretaries - the most senior civil servants in the Irish government - were Sir John Anderson and Sir James MacMahon; see Townshend, British campaign in Ireland, p. 80; Hopkinson, Irish War of Independence, p. 62.

${ }^{24}$ Borgonovo and Doherty, 'Smoking gun,' pp 37-8.

${ }^{25}$ Jones, Whitehall Diary, iii, 26: 'Mr. Churchill thought a formidable feature was the unanimity of the experts, with the exception of General Tudor'. 
'Both conditions of mind were disastrous', the Law Advisor concluded. ${ }^{26}$ If Dublin Castle was conducting a secret campaign of extrajudicial killings in the summer of 1920, then either Wylie was ignorant of this development, or concealed it from the cabinet. Neither possibility seems very likely.

As mentioned above, only Major-General Tudor disagreed with Wylie's appreciation of the Irish situation. The Police Adviser did say that 'he feared that the Royal Irish Constabulary could not last much longer, as they did not consider that they were being properly supported'. But unlike Wylie - or indeed, the rest of the Castle's top officials - Tudor welcomed the militarisation of the conflict. 'As a Police Force, he agreed with Mr Wylie, within a few months they would cease to function; but as a military body he thought they might have great effect.' More importantly, Tudor argued that, 'given the proper support, it would be possible to crush the present campaign of outrage'. But when asked what he meant by proper support, Tudor provided a list of emergency powers and population-control measures, including replacing civilian tribunals by courts martial; introducing identity cards; requiring passports to enter Ireland; restricting changes of domicile; deporting prisoners to Great Britain; and imposing collective fines on disturbed districts. He also thought that 'there should be a special penalty of flogging imposed for the cutting of girls' hair and outrages against women'. Armed with such emergency powers, and with enough police reinforcements, Tudor was confident he could control the situation: 'The whole country was intimidated, and would thank God for strong measures. ${ }^{27}$ If the Police Adviser's men were already trying to 'stamp out terrorism by secret murder,' he must have been concealing this fact from both his colleagues in the Castle and his political superiors in the cabinet.

But if the 'new policy and plan' mentioned by Prescott-Decie was not a campaign of assassination, then - what was it? The answer, once again, can be found in the work of historians like Charles Townshend - and, surprisingly, in the British press. During the winter of 1919-20, when Sir John Taylor was still assistant under-secretary, the Irish executive had tried to crush the movement for national independence with brute force. The army carried out extensive raids and searches, seizing arms and arresting wanted men. Republican activists were imprisoned, and many went on hunger strike in protest. ${ }^{28}$ But the appointment of Sir Hamar Greenwood as chief secretary for Ireland in April 1920 ushered in a period of what Townshend has called 'low-profile government'. The hunger strikers were let out of prison, and Sir John Taylor went on leave, never to return. The army adopted a defensive posture, the Dublin Castle administration was reorganised, and the British government tried to figure out what to do next. ${ }^{29}$ Months later, at the cabinet conference of 23 July 1920, William Wylie had fond memories of this period. 'When the new Administration had come over to Ireland

\footnotetext{
26 'The situation in Ireland. Notes of a conference with the officers of the Irish government held at 10, Downing Street, S.W. on Friday, 23rd. July 1920, at 11.30.a.m. and 3.30.p.m.' [Henceforward Cabinet conference 23 July 1920] (T.N.A., CAB 24/109 f. 445).

27 Cabinet conference 23 July 1920 (T.N.A. CAB 24/109 f. 450). This passage is misquoted in the hardcover edition of Leeson, The Black and Tans, p. 33: somehow, 'strong' became 'stern'.

${ }^{28}$ Townshend, British campaign in Ireland, pp 47-59.

${ }^{29}$ Townshend, British campaign in Ireland, pp 72-83.
} 
for six weeks there had been a lull in the Sinn Fein tactics of murder and outrage. This was caused by the hope that England would come forward and say that they were prepared to meet Sinn Fein. ${ }^{30}$

On 19 May 1920, the parliamentary correspondent for The Times reported that the government had reached a decision, and had settled on a new policy. In place of raids and searches, the military would establish 'a system of garrison posts and flying columns' in disaffected areas, using mobile troops in motor vehicles to patrol the countryside and engage in immediate pursuits of rebel bands. ${ }^{31}$ The man behind this new strategy was the Commander-in-Chief of British Forces in Ireland, General Sir Nevil Macready. The general had asked for reinforcements of both men and motor vehicles in early May, when a strike by Irish transport workers had disrupted the movement of troops and munitions by rail. ${ }^{32}$ At a cabinet conference held on 31 May 1920, Macready said:

My requisitions were put in two weeks ago. The troops are now stationary except the cavalry. The War Office is fulfilling my demands as fast as they can but they are held up by the strike, but even if we get what I have asked for the result of our policy will be gradual and depend very much on luck. ${ }^{33}$

The chief weakness of this optimistic new policy was its lack of any provision for strengthening the legal system. In its report of 19 May 1920, The Times had noted that, 'the problem which has hitherto baffled the Executive has been the twofold one of laying their hands upon the terrorists and then of obtaining sufficient evidence to secure their conviction. ${ }^{34}$ Indeed, the minutes for the cabinet conference of 31 May 1920 reveal that the British government was still baffled by this twofold problem. ${ }^{35}$ Subsequently, at the cabinet conference of 23 July 1920, Major-General Tudor came back to this problem once again: 'the two things which had given the Police a feeling of insecurity', the Police Adviser said, 'were (1) the release of the hunger-strikers, and (2) the fact that not a single criminal had been brought to justice for murder' ${ }^{36}$

In his letter of 1 June 1920, far from revealing plans for a secret campaign of assassination reprisals, Prescott-Decie was discussing this problem as well: 'I beg to report that the state of this Division is steadily getting worse'.

The efforts of the Sinn Feiners are principally directed to getting rid of the Police, so that the Laws of Kingdom may become wholly inoperative. For the same reason they are endeavouring to reduce all Courts of Justice, and Inquests to a farce. In lieu of British courts, they are establishing their own.

'The Sinn Fein method of maintaining their hold is very simple,' the letter explains: 'they threaten all who oppose them and if that is not sufficient murder

${ }^{30}$ Cabinet conference 23 July 1920 (T.N.A. CAB 24/109 f. 448).

31 'To fight the terror,' The Times, 19 May 1920, p. 16.

32 Townshend, British campaign in Ireland, pp 83-5.

33 Jones, Whitehall Diary, iii, 18. Macready had the full support of the chief secretary, who told the cabinet that the first order of business was to 'fulfill all military requisitions made by General Macready' and explained that, instead of proclaiming martial law, he would rather 'try to wait for Macready's requisitions and go on trying to get moderate opinion on our side'.

34 'To fight the terror,' The Times, 19 May 1920, p. 16.

35 Jones, Whitehall Diary, iii, 16-23.

${ }^{36}$ Cabinet conference 23 July 1920 (T.N.A. CAB 24/109 f. 449). 
them. The Loyal people and the Law abiding people who are considerable in number are completely terrorised.'

This was the 'terrorism by secret murder' to which Prescott-Decie was referring - and which he doubted the 'new policy and plan' would succeed in stamping out. And by the end of the summer, the same situation had indeed recurred, just as the divisional commissioner had predicted. Once it became clear that the government would not negotiate, the insurgency resumed in earnest. As Wylie told the cabinet on 23 July 1920, 'during the last fortnight things had become worse than they had ever been before' ${ }^{37}$ Without the intelligence obtained from raids, arrests, and searches, the military's 'mobile troops' were ineffective..$^{38}$ When the summer assizes were held in June and July, they had to be adjourned across the south and west, when jurors refused to answer the summons. And once it became clear that the rebels were above the law, the police turned increasingly to reprisals in place of due process ${ }^{39}$ The British government responded to this debacle by reversing course once again - by passing the Restoration of Order in Ireland Act, and ultimately, by imposing martial law on the south.

It may well be that Prescott-Decie's letter makes no reference to reprisals at all. The divisional commissioner says that he still favours 'instant retaliation', and Borgonovo and Doherty have concluded that this meant 'reprisals'. But on 23 April 1920, General Macready had used this word in a very different sense, in a letter to the First Lord of the Admiralty, Walter Long:

I have impressed on my Generals (he wrote) the importance of taking no measures except in retaliation; that is to say, a murder or outrage is committed, and we at once retaliate by a raid for arms or persons in the immediate vicinity. ${ }^{40}$

As Borgonovo and Doherty themselves have written, 'The Prescott-Decie memo must be placed within the context of developments in the critical spring of $1920{ }^{\prime}{ }^{41}$ However, rather than considering this letter in its historical context, Borgonovo and Doherty have taken a single awkward phrase out of context, and used it as evidence for a conspiracy theory. ${ }^{42}$ Writing in the 1970s, Tom Bowden's interpretation of the letter was even more extreme. He argued that the "new policy and plan' for 'the stamping out of terrorism by secret murder' was nothing less than a vast conspiracy to assassinate the leaders of the Irish Republic - a conspiracy 'conceived by the secret service and carried out by the military and police forces in the form of reprisals' - a conspiracy that enjoyed 'the highest

${ }^{37}$ Cabinet conference 23 July 1920 (T.N.A. CAB 24/109 f. 448).

38 Townshend, British campaign in Ireland, pp 87-92. At the Cabinet conference of 31 May 1920, when asked if the authorities were 'getting a better type of evidence', Macready replied: 'Quite the other way', and admitted that his men were 'at present in very much of a fog'. 'Our old source of intelligence, raids, has been stopped': Jones, Whitehall Diary, iii, p. 22.

${ }^{39}$ Leeson, The Black and Tans, pp 10-11, 43-4.

${ }^{40}$ Quoted in Townshend, British campaign in Ireland, p. 83.

${ }^{41}$ Borgonovo and Doherty, 'Smoking gun,' p. 38.

42 Philosopher David Coady has defined conspiracy theories as 'conspiratorial explanations that are inconsistent with official explanations of the time and place in question': David Coady, 'An introduction to the philosophical debate about conspiracy theories' in David Coady (ed.) Conspiracy theories: the philosophical debate (Aldershot and Burlington, VT, 2006), pp 1-12, at p. 3. 
official support' and 'may well have originated' with the prime minister or the Chief of the Imperial General Staff (or perhaps the under-secretary for Ireland). ${ }^{43}$

Bowden looked backward, and connected the 'new policy and plan' to a series of 'death notices' received by members of Dáil Eireann in mid-May $1920{ }^{44}$ Borgonovo and Doherty have looked forward, and found an equally tenuous link between the Prescott-Decie letter and the Listowel police mutiny of mid-June. On this occasion, they claim, another divisional commissioner made remarks that 'echoed the sentiments expressed by Prescott-Decie' ${ }^{45}$ In a speech to disaffected police constables at Listowel, County Kerry, on 19 June 1920, LieutenantColonel Gerald Smyth urged his men to shoot first and ask questions later. 'You may make mistakes occasionally and innocent persons may be shot', the divisional commissioner said, 'but this cannot be helped and you are bound to get the right persons sometimes. The more you shoot the better I will like you, and I assure you that no policeman will get into trouble for shooting any man. ${ }^{46}$

Like the rest of their argument, this is not very convincing. Yet even those historians who have rejected this type of conspiracy-theorising have not put Prescott-Decie's letter in its proper context. Though critical of Bowden's theory, Charles Townshend seems to have accepted that 'the stamping out of terrorism by secret murder' was a reference to unofficial reprisals ${ }^{47}$ David Fitzpatrick, by contrast, has concluded that the 'secret murder' was the work of the I.R.A.'s 'terrorists' rather than Crown forces. ${ }^{48}$ Yet, taking the 'new policy and plan' to be a reference to policing procedure, Fitzpatrick has remarked on the 'curious' fact that 'the new policy was not conveyed through regular police channels, and that it proposed deterrent rather than retaliatory action'.$^{49}$ It must, he concludes, have been a reference to the relaxation of official restrictions on the use of weapons, and 'the police being encouraged to shoot and kill suspected armed rebels after a perfunctory challenge' ${ }^{50}$ And when Divisional Commissioner Smyth gave his speech to the police at Listowel, he was merely describing these new rules of engagement. ${ }^{51}$

${ }^{43}$ Bowden, Breakdown of public security, pp 118-21.

${ }^{44}$ On 14-16 May 1920, a number of T.D.s received threatening letters, typed on official Dáil Eireann stationery. These letters were traced back to the typewriter of a British military intelligence officer working in Dublin Castle. In addition, this officer's captured correspondence included a cryptic reference to a 'little stunt'. From these few facts, Irish republicans concluded that they had uncovered a military murder plot - a carefullyplanned false-flag operation, in which the murders of republican leaders would be blamed on republican 'extremists'. See 'An amazing series of documents' in Irish Bulletin, 10 Sept. 1920, pp 1-5; Frank Gallagher, The four glorious years (Dublin, 1953), pp 89-94; Bowden, Breakdown of public security, pp 118-21.

${ }^{45}$ Borgonovo and Doherty, 'Smoking gun,' p. 39.

${ }^{46}$ The memoirs of Constable Jeremiah Mee, R.I.C., ed. J. Anthony Gaughan (Dublin, 1975), p. 104. Borgonovo and Doherty quote a slightly different version of this passage in 'Smoking gun,' p. 39.

${ }^{47}$ Townshend, 'Bloody Sunday,' p. 383 note 6.

${ }^{48}$ Fitzpatrick, 'R.I.C. reprisals'. Fitzpatrick is less definite on this point in The two Irelands: 'According to an alternative reading,' he says, 'this statement refers to the secret murder of (rather than by) terrorists and so confirms the alleged use of secret-servicemen to pursue and assassinate rebel ring-leaders.' (p. 91)

${ }^{49}$ Fitzpatrick, Politics and Irish life, p. 30.

${ }^{50}$ Fitzpatrick, The two Irelands, p. 91.

${ }^{51}$ Fitzpatrick, 'R.I.C. reprisals'. 
When it is realised, however, that the 'new policy and plan' was the one revealed in The Times on 19 May 1920, and discussed at the cabinet conference of 31 May 1920, all becomes clear. The new policy was not conveyed through regular police channels because it came down from the army's General Headquarters. Prescott-Decie was 'informed' of the new plan because, as a divisional commissioner, one of his duties was to liaise between the police and the military, and improve communication and coordination between the R.I.C. and the army. ${ }^{52}$ The brigadier expressed scepticism about this new military strategy: he still preferred 'instant retaliation' by raids, arrests and seizures. Nonetheless, once the police receive the support they have been promised, 'we shall know how to employ it in carrying out the policy outlined to me. Meanwhile we hang on.'

The promised support was on its way. As the leader of the Listowel police mutiny says in his memoirs: 'British troopships began to land troops all round the south coast of Ireland, from Wexford to Limerick. These troops began to move inland and take up strategic positions convenient to all the important centres of population. Buildings were commandeered to accommodate the troops, as military barracks were already full. ${ }^{53}$ One of these buildings was the R.I.C. station at Listowel, County Kerry. On 16 June, the local district inspector was informed that most of his men were being transferred, and that the police barracks would be handed over to the military the following day. But the police at Listowel refused to move, and even gave their notice when their county inspector ordered them to cooperate..$^{54}$

Divisional Commissioner Smyth came to Listowel R.I.C. barracks on 19 June, accompanied by police, troops, and the Police Adviser, Major-General Tudor. The mutinous police were assembled in the dayroom, where Smyth explained their part in the new policy and plan. The army, he said, was 'to take possession of the large centres where they will have control of the railways and lines of communication, and be able to move rapidly from place to place.' The police in these large centres would be redistributed to smaller stations. There, instead of waiting for the rebels to attack, they would send out frequent patrols. In particular, the police would conduct ambush patrols, going out at night and waiting in ambush, ready to open fire on anyone who did not put up their hands when challenged, and even opening fire without warning on suspicious persons ${ }^{55}$ It was in this context - an explanation of the 'new policy and plan' of patrol and pursuit - that Smyth made (or perhaps did not make) his controversial remarks..$^{56}$

\footnotetext{
52 Townshend, British campaign in Ireland, p. 56.

${ }^{53}$ Memoirs of Constable Jeremiah Mee, p. 91.

${ }^{54}$ Ibid., pp 93-9.

${ }^{55}$ Ibid., pp 99-104.

${ }^{56}$ Jeremiah Mee's account of Smyth's remarks was published in the Freeman's Journal newspaper on 10 July 1920. In response, Smyth produced a report that contradicted Mee's version in several places, dated 13 July 1920, four days before the divisional commissioner was assassinated by the I.R.A. In particular, Smyth's report gives a completely different interpretation for the phrase 'no policemen will get into trouble for shooting any man.' According to the divisional commissioner's version, he told the police at Listowel that the names of constables involved in shootings would not be revealed at inquests, to protect them from being targeted by the I.R.A. (ibid., pp 294-301).
} 
And yet, Borgonovo and Doherty were close to the truth here. Something did happen at Listowel on 19 June 1920 that helps explain R.I.C. reprisals in the War of Independence. According to Jeremiah Mee, the Listowel mutineers were expecting their actions to have serious consequences. When armed police arrived at the barracks on the morning of 19 June, 'we were convinced that we were all for dismissal'; then, when soldiers arrived, they suspected 'that this display of force could mean only one thing - a military court-martial which could result in some of us being shot. ${ }^{57}$ Instead, once it was clear that the mutineers would not back down, Major-General Tudor spoke to them in a friendly way, shook their hands, and explained that, though he was an Englishman, his ancestors had come from Ireland. 'He then explained that Dominion Home Rule, applying to all Ireland, was to come into operation in the near future and that the R.I.C. would come out well under the new arrangement; that, for instance, they would get twelve years added to their service for the purpose of pensions.' Tudor also promised that small and isolated police posts in the district would be closed, and finally, both he and the divisional commissioner left without taking any further action. ${ }^{58}$ Though five of the disaffected police (including Jeremiah Mee) did eventually resign, there is no record of any of them being punished for insubordination.

Tudor's actions at Listowel on 19 June 1920 were consistent with his actions twelve weeks later, in Galway, on 8 September 1920. This was the night that

Borgonovo and Doherty have rejected any suggestion that Mee's account of this incident has been distorted or exaggerated. 'The British government', they say, 'was aware of the problem of contradicting the sworn testimony of its own policemen, trained by it in the art of recording verbatim speech, whose testimony in such matters had for decades been relied upon without question by its own courts. It therefore concocted a (mercifully transparent) whispering campaign, the thrust of which was that the constables involved (experienced policemen all) had wilfully misrepresented Smyth's words for nefarious and selfish purposes' (Borgonovo and Doherty, 'Prescott-Decie letter').

In fact, it was not uncommon for the police to give false witness during the War of Independence: indeed, the problem eventually grew so serious that Assistant UnderSecretary Mark Sturgis complained in his diary that some Castle officials were assuming that 'every single report of every single police man must be lies from start to finish': The last days of Dublin Castle: the diaries of Mark Sturgis, ed. Michael Hopkinson (Dublin, 1999), p. 136. On 21 February 1920, Deputy Inspector General Walsh even issued a circular on the subject. 'It has been said and suggested in the House of Commons that some Police reports are not true and are intended to mislead. The Chief Secretary regards this as incredible but he desires to make it clear that if any policemen, no matter what his rank, makes any report intended to mislead his authorities, he will be dismissed from the Force and lose all pension and other rights.' R.I.C. circular, 'Alleged false police reports', 21 Feb. 1921 (T.N.A., HO 184/126).

Some aspects of Mee's account do seem problematical. According to Mee, for example, the divisional commissioner hinted that the government was planning to drown Irish revolutionaries at sea: 'A ship will be leaving an Irish port in the near future with lots of Sinn Féiners on board. I assure you, men, it will never land' (Memoirs of Constable Jeremiah Mee, p. 104). No such noyade ever took place. Finally, as the leader of the Listowel police mutiny, Jeremiah Mee can hardly be considered an impartial witness to these events, any more than Smyth can. My own sense is that neither version of the divisional commissioner's remarks is entirely trustworthy.

${ }^{57}$ Memoirs of Constable Jeremiah Mee, pp 101-2.

${ }^{58}$ Ibid., pp 107-8. 
Volunteer John Mulvoy was shot dead at Galway railway station by a Black and Tan, Edward Krumm. The police constable was then shot dead in turn, by Mulvoy's comrades. When word of this affray reached the city's R.I.C. barracks, the police rioted, executing a second Volunteer, Seamus Quirke, and wounding a third. They also shot up the streets, set fire to homes, and wrecked the machinery of a republican newspaper. General Tudor was in Galway that night, and spoke to the city's police the following day. Once again, his words were friendly. Once again, he promised his men that Home Rule was coming, along with a pay raise, additional weapons and equipment, and reinforcements. And once again, no disciplinary action was taken. ${ }^{59}$ In both cases, it seems that in the mind of the Police Adviser, his men required sympathy and encouragement, rather than discipline and punishment.

By the spring and summer of 1920, the R.I.C. did not require incitement from Dublin Castle to commit reprisals. The Irish Republican Army was already inciting violence among the police - by killing and wounding them, setting fire to their stations, undermining the legal system they served, and encouraging their communities to boycott them. What the R.I.C. needed in the spring and summer of 1920 was not incitement, but restraint. At the moment when they should have tightened the reins of police discipline, the authorities loosened them instead. After their comrades got away with mutiny, riot, and murder, in Listowel, Galway, and other Irish communities, the men of the Royal Irish Constabulary drew the appropriate conclusion. ${ }^{60}$ So long as they stayed within the margin of tolerated illegality - so long as they retaliated against republican activists and militants, and spared the lives and property of 'civilians' - the police, like the guerrillas, were above the law. By the late autumn of 1920 even Major-General Tudor felt compelled to admonish his men to stay within these very generous parameters of acceptable behaviour. ${ }^{61}$ But by praising his men with such faint condemnation, the Police Adviser only helped ensure that reprisals would continue.

D. M. LEESON

Department of History, Laurentian University

\footnotetext{
${ }^{59}$ Leeson, The Black and Tans, pp 45-6; see also D. M. Leeson, 'The curious case of Constable Krumm,' Canadian Journal of Irish Studies (forthcoming).

${ }^{60}$ Last Days of Dublin Castle ed. Hopkinson, p. 95: according to Sturgis, 'these men have undoubtedly been influenced by what they have taken to be the passive approval of their officers from Tudor downwards to believe they will never be punished for anything.'

${ }^{61}$ In a memorandum on discipline dated 12 Nov. 1920, Tudor told his men that 'there must be no wild firing from lorries,' that 'there must be no arson or looting,', and that the cutting of women's hair would not be tolerated, R.I.C. circular, 'Discipline,' 12 Nov. 1920, (T.N.A., HO 184/126). In a further circular, dated 6 Dec. (less than a week before the burning of Cork), the Police Adviser said: 'I wish again to impress on all members of Police Force the absolute necessity of stopping burnings whatever the provocation': R.I.C. circular, 'Burning of houses \&c.', 6 Dec. 1920 (T.N.A., HO 184/126). There was, however, no mention of any punishment for police who did not follow the Police Adviser's 'guidance'.
} 


\section{Appendix: the Prescott-Decie Letter}

\section{$\underline{\text { Secret }}$}

MUNSTER No. 1 DIVISION

Divisional Commissioners Office Limerick. 1st June 1920.

To the Assistant Under Secretary

I beg to report that the state of this Division is steadily getting worse. The efforts of the Sinn Feiners are principally directed to getting rid of the Police, so that the laws of Kingdom may become wholly inoperative. For the same reason they are endeavouring to reduce all Courts of Justice, and Inquests to a farce. In lieu of British Courts, they are establishing their own. County Kilkenny at present seems a favourite spot for these courts. Probably because it is so weakly garrisoned with Police and Military. The Sinn Fein method of maintaining their hold is very simple, they threaten all who oppose them and if that is not sufficient murder them. The Loyal people and the Law abiding people who are considerable in number are completely terrorised. The openly say "What is the good of being Loyal to the British government which let us down every time"., A fine old man said to me yesterday "my three sons were killed in the War, my only daughter died of disease while nursing, and now I am being robbed of my land, and yet I am loyal? God knows why"

The situation with the police themselves has been very ticklish. They have been very near throwing up the sponge. They consider that they have been let down by the Government and that they have been unsupported. Their arguments are hard to find answers to. Let no one suppose they are frightened - they are not. I dont wish to blow my own trumpet, but merely to show how close a shave it has been, in saying they have been held together by the influence of myself, and the Officers of the R.I.C. Major General Tudor's visit was of great value. We can hold them now for a time but if the support promised was to fail, the situation would be, I fear, beyond retrieving. I have been told the new policy and plan and I am satisfied, though I doubt its ultimate success in the main particular - the stamping out of terrorism by secret murder. I still am of opinion that instant retaliation is the only course for this, and until it is stamped for good and all, the same situation is likely to recur. The I.R.A. are improving their Organization. I expect more and better prepared attacks on Barracks.

I trust that now any demands of mine will be more promptly met. It is unnecessary I think to say more at this moment. When the support we are promised arrives, we shall know how to employ it in carrying out the policy outlined to me. Meanwhile we hang on.

[Signed] C. Prescott Decie Brig. Genl. 